\title{
Penyadaran Masyarakat Akademik tentang Peranan Herbal dalam Peningkatan Sistem Imun
}

\author{
Diah Mustikasari ${ }^{1}$, Andri Kurniawan ${ }^{2}$, Pipit Rakhmawati ${ }^{3,4}$ \\ ${ }^{1}$ Jurusan Biologi, Universitas Wanita Internasional \\ ${ }^{2}$ Jurusan Akuakultur, Universitas Bangka Belitung \\ ${ }^{3}$ Rumah Herbal Maharaja, RHM Foundation, Depok, Jawa Barat \\ ${ }^{4}$ Kementerian Pertanian RI, Jakarta \\ E-mail: 1diah.mustikasari83@gmail.com, ${ }^{2}$ andri_pangkal@yahoo.co.id, ${ }^{3}$ pietly1@gmail.com
}

\begin{abstract}
Abstrak
Sistem imun merupakan suatu mekanisme pertahanan tubuh yang terintegrasi untuk mencegah, menghambat, dan mengeliminasi antigen hingga memperbaiki sel atau jaringan tubuh yang terinfeksi. Sistem imun yang dikelompokkan menjadi innate immunity dan adaptive immunity adalah kekuatan natural di dalam tubuh yang dapat dioptimalkan untuk menjaga eksistensi kehidupan. Aktivitas pengabdian ini bertujuan untuk meningkatkan kesadaran mahasiswa sebagai bagian dari klaster masyarakat akademik terkait peranan herbal dalam peningkatan sistem imun (imunitas). Kegiatan ini dilakukan melalui sosialisasi dan focus group discussion (FGD) secara daring (online) yang melibatkan mahasiswa dan alumni Universitas Bangka Belitung. Hasil dari kegiatan ini adalah adanya peningkatan pemahaman mahasiswa dan alumni terkait sistem imun, yaitu jenis, peranan, dan mekanisme pertahanan tubuh baik secara seluler maupun humoral serta pemahaman tentang peranan herbal di dalam sistem imun tersebut. Hasil diskusi ini diharapkan dapat memberikan pengetahuan dan peningkatan kesadaran terhadap pentingnya sistem imun di dalam kehidupan.
\end{abstract}

Kata kunci: herbal, sistem imun, innate immunity, adaptive immunity, pengabdian dosen.

\begin{abstract}
The immune system is an integrated body defense mechanism to prevent, inhibit, and eliminate antigens and also to repair infected cells or tissues. The immune system, which is grouped into innate immunity and adaptive immunity, is a natural force in the body that can be optimized to maintain the existence of life. This activity aimed to increase the awareness of students as part of the academic community cluster regarding the role of herbs in enhancing the immune system (immunity). This activity was carried out through an online socialization and focus group discussion (FGD) involving students and alumnus from Bangka Belitung University. The result of this activity was an increased understanding of students and alumus related to the immune system, namely the types, roles, and defense mechanisms of the body both cellular and humoral as well as an understanding of the role of herbs in the immune system. The results of this discussion were expected to provide knowledge and increase awareness of the importance of the immune system in life.
\end{abstract}

Keywords: herbs, immune system, innate immunity, adaptive immunity, dedication of lecturer.

\section{PENDAHULUAN}

Peningkatan kesadaran terkait kesehatan harus menjadi perhatian berbagai pihak. Hal ini dikarenakan tantangan kesehatan yang dihadapi oleh manusia semakin meningkat akibat perubahan lingkungan yang memunculkan sumber penyakit. Sosialisasi terkait kesehatan 
menjadi salah satu unsur penting untuk membantu memberikan pemahaman dan peningkatan kesadaran masyarakat tentang arti penting atau urgensi kesehatan secara menyeluruh. Kesadaran kesehatan adalah suatu bentuk kepedulian dan perhatian untuk menjadi lebih baik dan termotivasi dalam memperbaiki, mempertahankan, menjaga kesehatan dan kualitas hidup dengan menerapkan pola hidup sehat [1].

Masyarakat akademik adalah salah satu ujung tombak perubahan yang diharapkan dapat membantu meningkatkan kesadaran kesehatan di tengah masyarakat umum. Hal ini menjadi dasar bahwa masyarakat akademik mempunyai peranan yang sangat penting dalam mengawal perubahan masyarakat [2], khususnya dalam bidang kesehatan diri dan lingkungannya.

Sosialisasi dan pendekatan akademis harus terus diupayakan untuk meningkatkan kepedulian masyarakat, termasuk masyarakat akademik terhadap kesehatan, sistem imun, dan herbal. Ketiga komponen ini secara langsung maupun tidak langsung tidak dapat dipisahkan keterkaitannya. Kesehatan tubuh sangat ditentukan oleh kekuatan sistem imunitasnya dan herbal menjadi salah satu bahan pendukung untuk menguatkan sistem imunitas tersebut.

Sosialisasi dan pendekatan akademik yang selama ini dilakukan baru sebatas brainstorming melalui forum non formal untuk membahas terkait peranan sistem imun bagi kesehatan organisme. Diskusi-diskusi formal seperti focus group discussion (FGD) dipandang perlu untuk mendiskusikan hal tersebut secara lebih ilmiah. Upaya tersebut juga diperlukan untuk melihat pandangan dan penguatan dari akademisi maupun praktisi terkait kesehatan, sistem imun, dan herbal. Bertitik tolak dari hal tersebut, maka kegiatan pengabdian berupa sosialisasi dan diskusi terkait sistem imun dan peranan herbal dalam manajemen kesehatan dilakukan pada masyarakat akademik. Hal ini bertujuan untuk memberikan dan meningkatkan pemahaman serta kesadaran masyarakat akademik terkait pentingnya sistem imun dan peranan herbal dalam sistem imun tersebut. Kegiatan ini diharapkan dapat mendorong peningkatan pemahaman masyarakat luas terkati eksistensi herbal dalam menjaga dan mempertahankan daya tahan tubuh atau imunitasnya.

\section{METODE}

Kegiatan pengabdian masyarakat ini dilakukan dalam bentuk sosialisasi dan focus group discussion (FGD) secara daring (online) kepada mahasiswa dan alumni Universitas Bangka Belitung sebagai bagian dari klaster masyarakat akademik. Hasil dari kegiatan pengabdian ini dideskripsikan dalam bentuk tabel, grafik, maupun foto dokumentasi sehingga dapat memberikan gambaran dan capaian dari kegiatan pengabdian masyarakat tersebut.

\section{HASIL DAN PEMBAHASAN}

1. Peningkatan Pemahaman tentang Sistem Imun dan Herbal

Mahasiswa dan alumni yang menjadi sasaran sosialisasi berasal dari beberapa jurusan yang tidak berkaitan dengan bidang kesehatan manusia. Hal ini bertujuan untuk mensosialisasikan informasi dan mengetahui pemahaman mereka terkait kesehatan manusia, khususnya berkaitan dengan sistem imun atau sistem pertahanan tubuh.

Peningkatan pemahaman dilakukan melalui focus group discussion (FGD) secara daring (online) dengan pemaparan materi berupa sistem imun dan peranan obat tradisional dalam manajemen kesehatan. Beberapa tangkapan layar (screenshot) materi sosialisasi ditampilkan pada Gambar 1. Teknik FGD adalah salah satu metode pengumpulan data kualitatif yang banyak digunakan, khususnya oleh pembuat keputusan atau peneliti dalam penelitian kualitatif. Teknik FGD digunakan untuk menggali data mengenai persepsi, opini, kepercayaan dan sikap terhadap suatu produk, pelayanan, konsep atau ide karena relatif lebih mudah dan cepat selesai dibandingkan dengan teknik pengumpulan data kualitatif yang lain [3]. Metode ini memiliki karakteristik utama yaitu menggunakan data interaksi yang dihasilkan dari diskusi diantara para partisipannya. Kekuatan utama metode FGD terbukti dapat memberikan data yang lebih mendalam, lebih informatif, dan lebih bernilai dibanding metode lainnya [4]. 

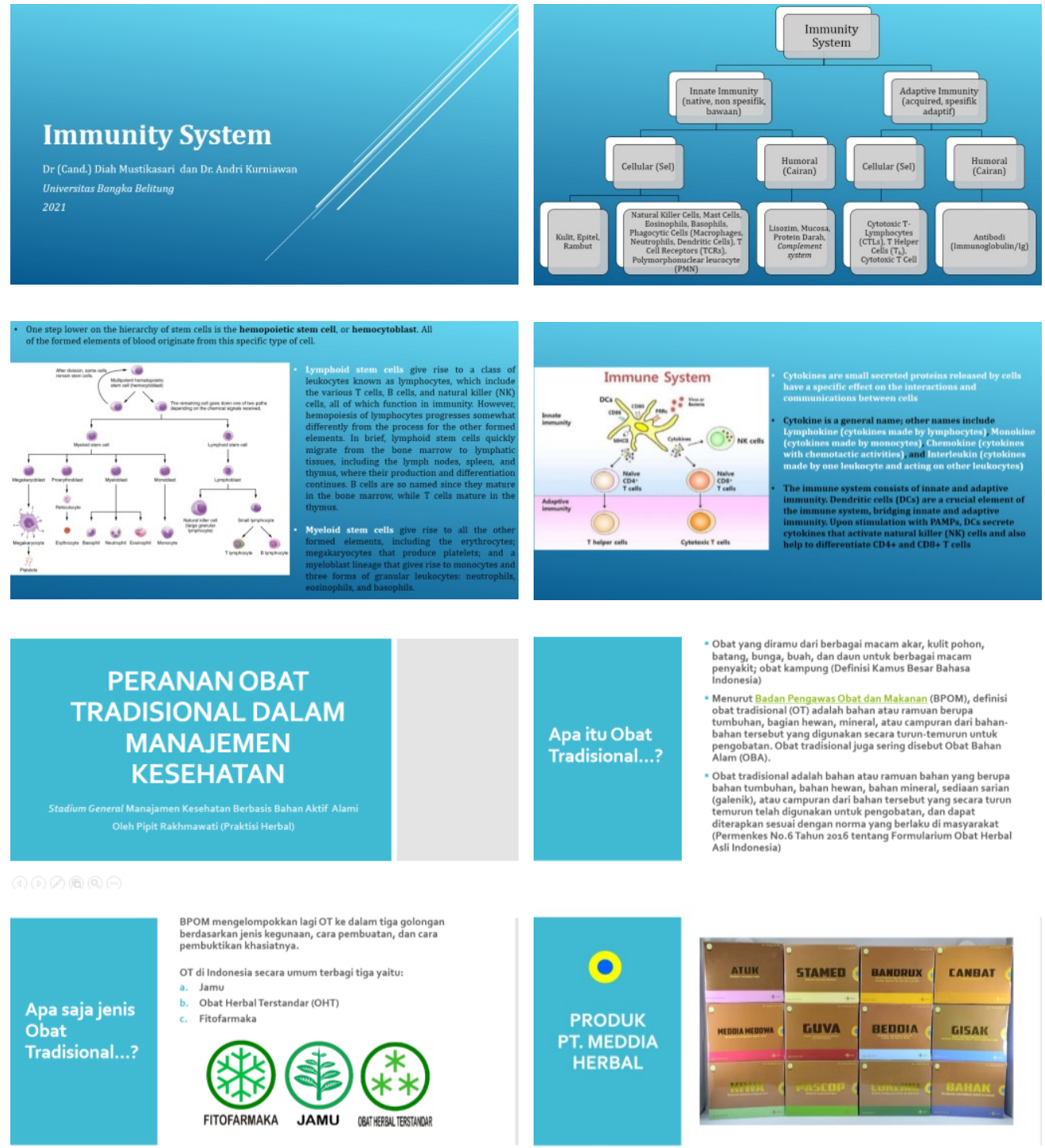

Gambar 1. Tangkapan Layar Materi Sosialisasi.

Kegiatan sosialisasi dan FGD menjadi forum diskusi untuk meningkatkan pengetahuan dan pemahaman tentang materi yang diberikan, yaitu sistem imun dan peranan herbal di dalam meningkatkan sistem imun tersebut. Penyadaran tentang sistem imun menjadi sangat penting dikarenakan tubuh manusia setiap harinya menghadapi ancaman dari serangan sumber penyakit (antigen) yang berupaya memasuki tubuh manusia dengan berbagai cara seperti melalui sistem pernapasan, sistem pencernaan, dan sistem lainnya. Tubuh mengembangkan sistem innate immunity (sistem imun bawaan) dan adaptive immunity (sistem imun spesifik) untuk mempertahankan eksistensi tubuh dari serangan antigen tersebut [5].

Informasi dan pemahaman yang disampaikan kepada peserta FGD mampu menghasilkan interaksi yang komunikatif di dalam pendalaman materi terkait sistem imun tubuh manusia. Hal ini menjadi tambahan wawasan bagi peserta di dalam memahami suatu komponen penting di dalam tubuhnya yang berperan untuk menjaga eksistensi dan kesehatan dirinya.

Hasil FGD menunjukkan bahwa mahasiswa dan alumni memahami artipentingnya kesehatan tubuh. Salah satu upaya yang dapat dilakukan untuk menjaga kesehatan tubuh tersebut adalah meningkatkan peranan sistem imun melalui konsumsi ramuan tanaman herbal. Hasil FGD menjelaskan bahwa $100 \%$ peserta memahami tentang artipentingnya kesehatan, 
sebesar $80 \%$ memahami tentang peranan sistem imun bagi kesehatan tubuh, serta sebesar $88 \%$ memahami tentang peranan herbal bagi penguatan dan peningkatan sistem imun tersebut sebagaimana ditampilkan pada Gambar 2.

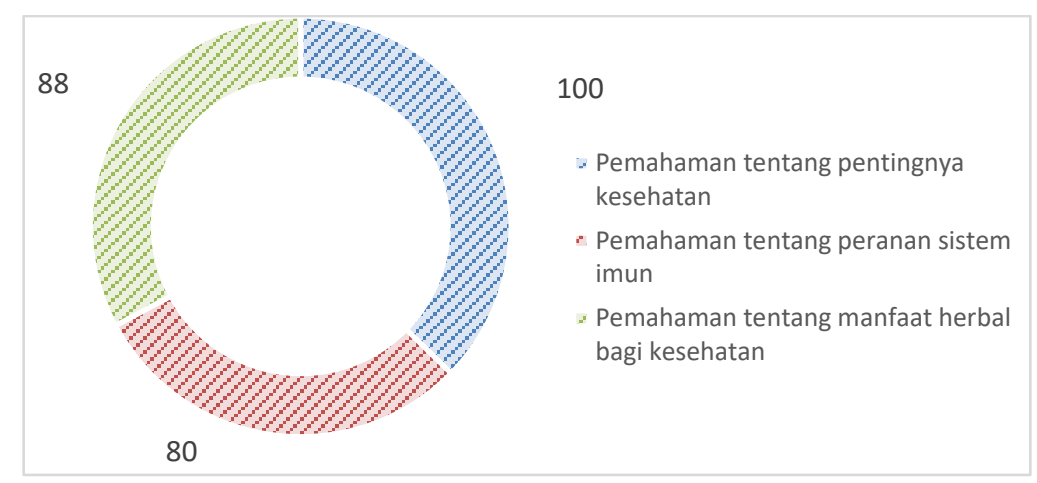

Gambar 2. Tingkat Pemahaman Peserta Terkait Kesehatan, Sistem Imun, dan Manfaat Herbal.

Hasil tersebut memberikan gambaran bahwa secara umum pemahaman masyarakat akademik terkait kesehatan, sistem imun, dan manfaat herbal sudah baik. Hal tersebut perlu mendapatkan perhatian agar pemahaman tersebut dapat disebarluaskan kepada masyarakat umum sehingga semakin banyak masyarakat yang peduli pada kesehatan masyarakat (public health). Penguatan sistem imun masyarakat melalui tanaman herbal menjadi salah satu upaya konkret untuk menjadikan kekayaan dan warisan leluhur Bangsa Indonesia sebagai media penjaga kesehatan negara.

2. Peranan Herbal pada Sistem Imun

Indonesia memiliki potensi tanaman obat yang luar biasa secara kualitas dan kuantitas. Berbagai tanaman obat tersebut telah lama digunakan dan diyakini memiliki kemampuaan pengobatan dan pencegahan dari berbagai macam penyakit [6]. Tanaman obat atau herbal merupakan tanaman atau bagian tanaman seperti daun, akar, biji, dan bunga yang memiliki khasiat obat karena memiliki sejumlah senyawa kimiawi (chemical compounds) yang dapat bekerja bersama secara sinergistik untuk terapi ataupun pengobatan [7].

Beberapa senyawa aktif dari hasil skrining fitokimia tanaman herbal antara lain senyawa flavonoid, saponin, steroid, alkohol, aldehide, senyawa aromatik, terpenoid, fenolik, tanin, glikosida, dan lainnya $[8,9,10]$ yang dapat berperan sebagai antikanker, antimikroba, anti-ulcerogenik, antivirus, antioksidan, analgesik, anti-inflamantori, aktivitas sitotoksik, aktivitas penyembuhan, dan efek terapeutik lainnya [11, 12].

Pemanfaatan herbal untuk meningkatkan kesehatan berupa daya tahan tubuh (imunitas) menjadi tema yang banyak didiskusikan. Berbagai penelitian telah menunjukkan bahwa senyawa aktif dari herbal dapat meningkatkan aktivitas fagositosis dan sistem kekebalan innate (bawaan) serta penguatan sistem kekebalan adaptive (spesifik) berupa antibodi [13].

Hasil sosialisasi dan FGD menunjukkan bahwa antusiasme peserta dalam mengelaborasi materi terkait sistem imun dan pemanfaatan herbal untuk kesehatan sangat tinggi. Hal ini menjadi unsur yang penting sebagai kekuataan akademik di dalam menumbuhkan kesadaran tentang artipentingnya kesehatan, sistem imun, dan peranan herbal.

3. Industrialisasi Jamu

Informasi pengetahuan dan pemahaman terkait potensi sumber daya alam Indonesia berupa tanaman obat serta peranannya bagi kesehatan menjadi materi yang menarik di dalam kegiatan diskusi FGD. Kegunaan dan pemanfaaan Herbal tidak dapat lagi dianggap hanya sebagai ramuan tradisional yang hanya dimanfaatkan oleh kalangan masyarakat tradisional. Lapisan masyarakat urban dan terdidik juga sudah mulai memanfaatkan herbal sebagai alternatif 
pengobatan maupun peningkatan daya tahan tubuh (imunitas). Produksi jamu yang berbasis tanaman obat atau herbal juga bukan hanya dilakukan oleh masyarakat tradisional, namun juga telah mengalami industrialisasi. Hal ini membuktikan bahwa segmentasi dan pemahaman masyarakat tentang peranan herbal untuk kesehatan semakin tumbuh dan berkembang dengan baik.

Berbagai bagian dari tanaman obat telah banyak diformulasikan menjadi produk jamu yang memenuhi standar dan perizinan Badan Pengawas Obat dan Makanan (BPOM). Beberapa jenis herbal atau bagian dari tanaman obat tersebut yang telah dimanfaatkan dalam skala industrialisasi ditampilkan pada Tabel 1 .

Tabel 1. Jenis Tanaman Herbal yang Digunakan dalam Produk Herbal

\begin{tabular}{|c|c|c|c|c|c|}
\hline No & Tanaman Herbal & No & Tanaman Herbal & No & Tanaman Herbal \\
\hline 1 & $\begin{array}{l}\text { Buah Adas (Feoniculii } \\
\text { fructus) }\end{array}$ & 10 & Apokat (Perseae folium) & 19 & $\begin{array}{l}\text { Kunyit (Curcumae longa } \\
\text { L. folium) }\end{array}$ \\
\hline 2 & $\begin{array}{l}\text { Kangkung Air (Ipomoea } \\
\text { aquatica folium) }\end{array}$ & 11 & Ubi jalar (Ipomoea batatas) & 20 & $\begin{array}{l}\text { Seledri (Apii graveolensis } \\
\text { folium) }\end{array}$ \\
\hline 3 & $\begin{array}{l}\text { Kunyit (Curcumae } \\
\text { domesticae rhizome) }\end{array}$ & 12 & $\begin{array}{l}\text { Keji Beling (Sericocalycis } \\
\text { folium) }\end{array}$ & 21 & $\begin{array}{l}\text { Belimbing Wuluh (Bilimbi } \\
\text { fructus) }\end{array}$ \\
\hline 4 & $\begin{array}{l}\text { Jahe (Zingiberis } \\
\text { rhizome) }\end{array}$ & 13 & $\begin{array}{l}\text { Kencur (Kaempferiae } \\
\text { folium) }\end{array}$ & 22 & $\begin{array}{l}\text { Meniran (Phyllanthi } \\
\text { folium) }\end{array}$ \\
\hline 5 & $\begin{array}{l}\text { Kencur (Kaempferiae } \\
\text { bulbus) }\end{array}$ & 14 & $\begin{array}{l}\text { Cengkeh (Caryophylli } \\
\text { folium) }\end{array}$ & 23 & $\begin{array}{l}\text { Daun Sirih (Piperis } \\
\text { folium) }\end{array}$ \\
\hline 6 & $\begin{array}{l}\text { Lengkuas (Languatis } \\
\text { rhizome) }\end{array}$ & 15 & Lidah Buaya (Aloe vera) & 24 & $\begin{array}{l}\text { Kemangi (Ocimi sancti } \\
\text { folium) }\end{array}$ \\
\hline 7 & $\begin{array}{l}\text { Daun Kumis Kucing } \\
\text { (Orthosiphonis folium) }\end{array}$ & 16 & $\begin{array}{l}\text { Bawang Putih (Allium } \\
\text { sativum) }\end{array}$ & 25 & $\begin{array}{l}\text { Rimpang Alang-alang } \\
\text { (Imperatae rhizome) }\end{array}$ \\
\hline 8 & $\begin{array}{l}\text { Daun Pare (Momordicae } \\
\text { folium) }\end{array}$ & 17 & $\begin{array}{l}\text { Bayam Berduri (Amaranthi } \\
\text { spinosi folium) }\end{array}$ & 26 & $\begin{array}{l}\text { Lada (Brucea amarissima } \\
\text { folium) }\end{array}$ \\
\hline 9 & Jarak (Ricini folium) & 18 & $\begin{array}{l}\text { Daun Sembung (Blumeae } \\
\text { folium) }\end{array}$ & 27 & $\begin{array}{l}\text { Daun Pepaya (Caricae } \\
\text { folium) }\end{array}$ \\
\hline
\end{tabular}

Ramuan tanaman obat tersebut telah diformulasikan oleh mitra di dalam kegiatan pengabdian masyarakat ini, yaitu PT. Meddia Herbal, Kutai Kertanegara, Kalimantan Timur yang diwakili oleh agen Rumah Herbal Maharaja, Depok. Ramuan herbal yang telah memperoleh izin edar dari BPOM adalah Bandrux (POM.TR. 073274 461), Atuk (POM.TR. 073273 971), Meddia Meddwa (POM.TR. 073273 961), Beddia (POM.TR. 083275 631), Stamed (POM.TR. 073274 451), Kiwa (POM. TR. 073273 971), Guva (POM. TR. 073274 051), Canbat (POM. TR. 083274 471), Pascop (POM. TR. 083275 621), Coklinu (POM. TR. 083278 731), Gisak (POM. TR. 083274 271), dan Bahak (POM.TR.073 274 941). Kedua belas produk tersebut telah dianalisis kandungan senyawa fitokimianya dan terdapat senyawa alkaloid, steroid, triterpenoid, flavonoid, tanin, saponin, dan quinon di dalam kesemua produk tersebut.

Kekuatan masyarakat akademik dapat menjadi media untuk meningkatkan pemahaman masyarakat umum untuk memahami potensi tanaman obat Indonesia serta pemanfaatannya, baik secara tradisional maupun skala industri. Dukungan masyarakat akademik terhadap industrialisasi jamu yang merupakan warisan leluhur Bangsa Indonesia menjadi pendorong bagi perkembangan jamu hingga menembus pasar global. Hal ini menjadi bagian penting di dalam menghadirkan kekuatan Indonesia di tengah pergaulan dunia melalui penyediaan sumber daya alam hayati berupa jamu yang dapat menjadi alternatif solusi pengobatan dan peningkatan sistem kekebalan tubuh (imunitas) masyarakat dunia. Kegiatan memasyarakatkan jamu Indonesia pada skala nasional maupun internasional mampu menghasilkan manfaat yang banyak, antara lain peningkatan kepedulian masyarakat terhadap produk kesehatan yang menjadi warisan budaya Indonesia, peningkatan kesadaran terhadap fungsi jamu atau herbal 
untuk menjaga dan meningkatkan sistem imunitas masyarakat, dan menduniakan Indonesia melalui produk jamu atau herbalnya.

\section{KESIMPULAN DAN SARAN}

Kegiatan pengabdian kepada masyarakat berupa sosialisasi dan peningkatan pemahaman masyarakat akademik, yaitu mahasiswa dan alumni terkait peranan herbal dalam peningkatan sistem imun adalah salah satu upaya penting untuk memberikan informasi penting terkait kesehatan dan peranan herbal untuk menjaga kesehatan tersebut. Mahasiswa dan alumni yang secara umum bukan berasal dari jurusan yang berkaitan dengan kesehatan memberikan respon yang baik terkait sosialisasi tersebut. Sosialisasi ini penting bagi mahasiswa dan alumni untuk meningkatkan pemahaman mereka terkait kesehatan berupa sistem imun dan peranan herbal di dalam meningkatkan sistem imun tersebut.

\section{UCAPAN TERIMA KASIH}

Ucapan terima kasih kami sampaikan kepada PT. Meddia Herbal, Kutai Kertanegara, Kalimantan Timur yang telah memberikan dukungan terhadap kegiatan pengabdian masyarakat ini.

\section{DAFTAR PUSTAKA}

[1] Michaelidou, N., Hassan, L., 2010, Modeling the Factors Affecting Rural Consumers' Purchase of Organic and Free-rangePproduce: A Case Study of Consumers' from the Island of Arran in Scotland, UK. Food Policy, No. 35, Vol. 2, 130-139

[2] Fadil, S., Usman, J., 2020, Sosialisasi dalam Rangka Pencegahan, Peningkatan Kesadaran dan Pemahaman Masyarakat tentang COVID-19 di Desa Panaguan Kec. Larangan. Perdikan: Journal of Community Engagement, Vol 2, No. 1, 42-53

[3] Paramita, A., Kristiana, L., 2013, Teknik Focus Group Discussion dalam Penelitian Kualitatif (Focus Group Discussion Tehnique in Qualitative Research). Buletin Penelitian Sistem Kesehatan, Vol. 16, No. 2, 117-127

[4] Afiyanti, Y., 2008, Focus Group Discussion (Diskusi Kelompok Terfokus) sebagai Metode Pengumpulan Data Penelitian Kualitatif. Jurnal Keperawatan Indonesia, Vol. 12, No. 1, 58-62

[5] Aripin, I., 2019, Value Education in Imun System Concept Materials. Jurnal Bio Educatio, Vol. 4, No. 1, 2541-2280

[6] Wijayakusuma, H. M. H., 2000, Potensi Tumbuhan Obat Asli Indonesia sebagai Produk Kesehatan. Risalah Pertemuan Ilmiah Penelilian dan Pengembangan Teknologi Isolop dan Radiasi, 2000, 25-31

[7] Kunle, O. F., Egharevba, H. O., Ahmadu, P. O., 2012, Standardization of Herbal Medicines - A Review. International Journal of Biodiversity and Conservation, Vol. 4, No, 3, 101-112

[8] Hossain, M. A., Al-Raqmi, K. A. S., Al-Mijizy, Z. H., Weli, A. M., Al-Riyami, Q., 2013, Study of Total Phenol, Flavonoids Contents and Phytochemical Screening of Various Leaves Crude Extracts of Locally Grown Thymus vulgaris. Asian Pacific Journal of Tropical Biomedicine, Vol. 3, No. 9, 705-710

[9] Das, N., Islam, Md. E., Jahan, N., Islam, M. S., Khan, A., Islam, Md. R., Parvin, M. S., 2014, Antioxidant Activities of Ethanol Extracts and Fractions of Crescentia cujete Leaves and Stem Bark and the Involvement of Phenolic Compounds. BMC Complementary and Alternative Medicine, Vol. 14, No. 45, 2-9

[10] Mujeeb, F., Bajpai, P., Pathak, N., 2014, Phytochemical Evaluation, Antimicrobial 
Activity, and Determination of Bioactive Components from Leaves of Aegle marmelos. BioMed Research International, 2014: 1-12

[11] Sasidharan, S., Chen, Y., Saravanan, D., Sundram, K. M., Latha, L. Y., 2011, Extraction, Isolation and Characterization of Bioactive Compounds from Plants' Extracts. African Journal of Traditional, Complementary and Alternative Medicines, Vol. 8, No. 1, 1-10

[12] Yousaf, Z., Wang, Y., Baydoun, E., 2013, Phytochemistry and Pharmacological Studies on Solanum torvum Swartz. Journal of Applied Pharmaceutical Science, Vol. 3, No. 4, 152-160

[13] Chen, M., Chen, R., Wang, S., Tan, W., Hu, Y., Peng, X., Wang, Y., 2013, Chemical Components, Pharmacological Properties, and Nanoparticulate Delivery Systems of Brucea javanica. International Journal of Nanomedicine, Vol. 8, 85-92 